\title{
Studi Penentuan Nilai Ekivalensi Mobil Penumpang (EMP) Pada Sepeda Motor Untuk Ruas Jalan 4/2D di Sidoarjo
}

\author{
Syafira Khayam ${ }^{1, *}$, Hera Widyastuti ${ }^{1}$ \\ Departemen Teknik Sipil, Institut Teknologi Sepuluh Nopember, Surabaya ${ }^{1}$ \\ Koresponden*, Email: khayamsyafira@gmail.com
}

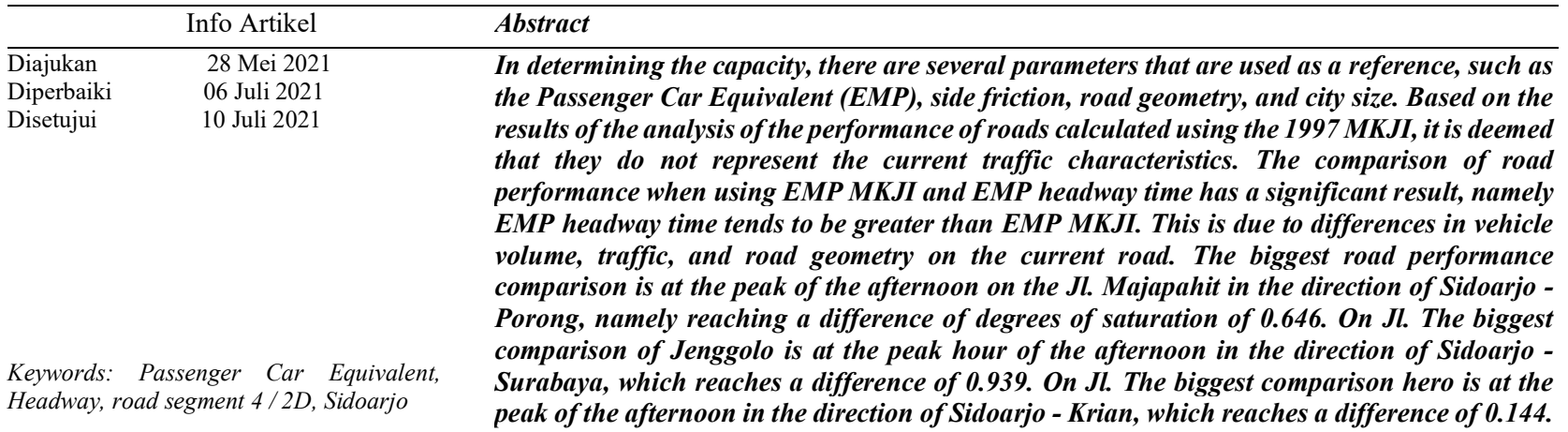

\begin{abstract}
Abstrak
Dalam menentukan kapasitas terdapat beberapa parameter yang dijadikan acuan, yaitu seperti Ekivalen Mobil Penumpang (EMP), hambatan samping, geometrik jalan, dan ukuran kota. Berdasarkan hasil Analisis kinerja ruas jalan yang dihitung menggunakan MKJI 1997 dirasa belum mewakili karakteristik lalu lintas yang ada saat ini. Perbandingan kinerja ruas jalan pada saat menggunakan EMP MKJI dan EMP headway memiliki hasil yang signifikan, yaitu EMP headway cenderung lebih besar dari EMP MKJI. Hal ini disebabkan karena adanya perbedaan volume kendaraan, karakteristik lalu lintas, geometrik jalan pada ruas jalan saat ini. Perbandingan kinerja jalan terbesar berada pada jam puncak sore pada ruas Jl. Majapahit arah Sidoarjo - Porong yaitu mencapai selisih derajat kejenuhan sebesar 0,646. Pada Jl. Jenggolo perbandingan terbesar berada pada jam puncak sore arah Sidoarjo - Surabaya yaitu mencapai selisih 0,939. Pada Jl. Pahlawan perbandingan terbesar berada pada jam puncak sore arah Sidoarjo - Krian yaitu mencapai selisih 0,144 .
\end{abstract}

Kata kunci: Ekivalen Mobil Pen
Headway, ruas jalan 4/2D, Sidoarjo

\section{Pendahuluan}

Bertambahnya jumlah kendaraan tiap tahun di Kota Sidoarjo dapat berakibat pada meningkatnya volume arus lalu lintas. Peningkatan volume harus dievaluasi dengan kapasitas jalan yang ada. Dalam menentukan kapasitas terdapat beberapa parameter yang dijadikan acuan, yaitu seperti Ekivalen Mobil Penumpang (EMP), hambatan samping, geometrik jalan dll. Berdasarkan beberapa hasil Analisis kinerja ruas jalan yang dihitung menggunakan MKJI 1997 belum mewakili karakteristik lalu lintas yang ada saat ini. Untuk itu perlu dilakukan penelitian lebih lanjut terhadap parameter parameter yang menentukan kinerja ruas jalan. Parameter yang diteliti pada thesis ini ialah Ekuivalen Mobil Penumpang (EMP).

Berdasarkan Manual Kapasitas Jalan Indonesia [1] telah diatur nilai emp untuk masing-masing ukuran kota namun seiring bertambahnya jumlah penduduk, bertambahnya jumlah kendaraan yang hampir mencapai angka 100.000 kendaraan untuk sepeda motor tiap tahunnya [2], berkembangnya wilayah, menjadikan MKJI 1997 perlu dikaji kembali terhadap kondisi lalu lintas saat ini. Dalam penentuan EMP sepeda motor, diambil studi kasus Jalan Perkotaan dengan tipe 4 lajur 2 arah di wilayah Sidoarjo.

Ekivalensi Mobil Penumpang (emp) adalah satuan arus lalu lintas dari berbagai tipe kendaraan yang diubah menjadi kendaraan ringan (termasuk mobil penumpang) dengan menggunakan faktor emp. Nilai ekivalensi mobil penumpang (emp) merupakan faktor konversi dari berbagai jenis kendaraan. Setiap jenis kendaraan mempunyai karakteristik pergerakan yang berbeda-beda karena kecepatan, dimensi, percepatan maupun kemampuan manuver. Ekivalensi mobil penumpang adalah berbagai jenis kendaraan yang dikonver- 
sikan pada satu jenis kendaraan (kendaraan mobil penumpang). Dimana nilai ini sangat bergantung pada keadaan lalu lintas, sistem antrian, dan jenis jalan raya yang dipilih [3].

\subsection{Perhitungan Nilai EMP}

Berbagai penelitian yang dilakukan para peneliti-peneliti untuk memahami tentang berbagai permasalahan tentang kapasitas pada ruas jalan. Beberapa peneliti menyatakan nilai ekivalensi mobil penumpang (emp) dapat dihitung dengan beberapa metode seperti : homogenization coefficient, semiemprical method, walker's method, multiple linear regression method, headway method, simulation method, and desinty method [4].

Terdapat beberapa parameter dalam menentukan kapasitas suatu ruas jalan. Salah satu parameter mikroskopik lalu lintas yang penting adalah Headway (waktu antara). Headway adalah selisih waktu kendaraan yang beriringan melewati suatu titik tertentu dalam satu lajur [5]. Ilustrasi headway dapat dilihat pada Gambar 1.

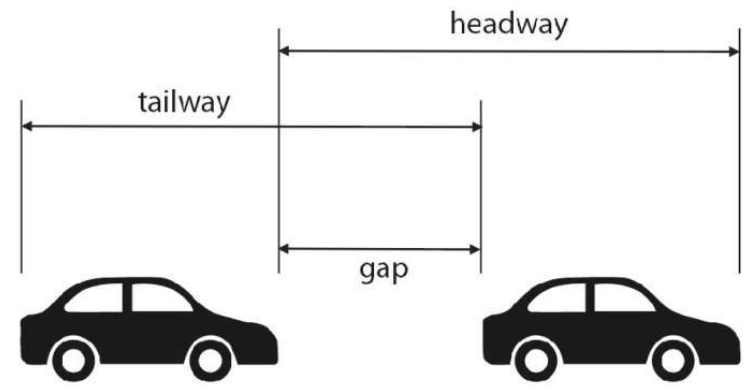

Gambar 1. Ilustrasi Headway [6]

Metode headway merupakan salah satu cara yang banyak digunakan untuk menentukan nilai emp, yaitu dengan cara mencatat waktu antara kendaraan yang berurutan pada saat kendaraan tersebut melewati titik yang telah ditentukan [5]. Metode Headway ini cocok digunakan untuk persimpangan atau jalan-jalan antar kota yang arus lalu lintasnya mengikuti disiplin tinggi, yaitu berjalan pada satu lajur beriringan sehingga waktu antara kendaraan menjadi jelas [7].

Metode Headway merupakan rasio rata-rata waktu antara kendaraan jenis tertentu dibagi dengan rata-rata waktu antara mobil penumpang [8]. Pencatatan waktu antara dengan metode ini dihitung dari bemper belakang kendaraan di depan dengan bemper belakang kendaraan yang mengikutinya.

Perbandingan metode kapasitas, metode kerapatan, dan metode headway untuk mencari nilai emp didapatkan kesimpulan bahwa metode headway merupakan metode yang paling tepat digunakan untuk mencari nilai emp pada jalan bebas hambatan [9].

Penelitian yang sama dengan menggunakan metode celah waktu pada ruas jalan TOL Jakarta-Cikampek dan didapat hasil perhitungan menunjukkan bahwa nilai emp cenderung berubah menjadi lebih besar jika dibandingkan dengan nilai emp MKJI 1997. Hasil perhitungan menemukan bahwa nilai emp untuk jenis kendaraan berat menengah berkisar antara 1,88-2,25 untuk jenis kendaraan truk besar berkisar antara $3,12-3,77$, dan untuk jenis kendaraan bus besar berkisar antara 1,52-1,64 [10].

Tujuan dari penelitian ini adalah untuk mengetahui karakteristik lalu lintas pada ruas Jl. Majapahit, J1. Raya Jenggala, dan J1. Pahlawan di Sidoarjo, untuk mengetahui nilai EMP yang mewakili kondisi lalu-lintas di Sidoarjo saat ini, dan untuk mengetahui perbandingan kinerja ruas jalan Ketika menggunakan EMP MKJI dengan EMP Headway.

\section{Metode}

Pengerjaan penelitian ini terdiri dari beberapa tahap yang harus dilakukan antara lain:

\subsection{Studi Literatur}

Studi Literatur dilakukan dengan cara mengumpulkan berbagai penelitian terdahulu, teori, maupun Text Book yang mendukung atau berkaitan dengan penelitian yang dilakukan.

Survei pendahuluan yaitu survei yang dilakukan sebelum penelitian, survei pendahuluan bertujuan untuk mengetahui kondisi eksisting pada lokasi penelitian seperti bagaimanakah kondisi lalu lintas pada lokasi yang ditinjau, bagaimanakah geometrik jalan yang ada pada lokasi tersebut, kemudian juga untuk menentukkan titik survei yang akan digunakan ketika pengambilan data primer.

\section{Survei Geometrik}

Survei pendahuluan telah dilakukan untuk menganalisis kondisi ruas jalan saat ini. Survei dilakukan pada tanggal 21 Juli 2019.

\section{Survei Lalu Lintas}

Survei lalu lintas dilakukan untuk mengetahui jam puncak pada ruas jalan yang ditinjau. Survei dilakukan mulai pukul 06.00 hingga pukul 19.00 dan dilaksanakan pada tanggal 15-17 Oktober 2019.

\subsection{Pengumpulan dan Pengolahan Data}

Data yang diperlukan dalam penelitian ini disesuaikan dengan analisis yang akan digunakan. Dalam hal ini terdapat 3 analisis data untuk menjawab masalah yang telah dirumuskan. Analisis data tersebut yaitu, analisis karakteristik lalu lintas, analisis penetapan nilai EMP, dan analisis kinerja ruas jalan.

\section{Analisis Karakteristik Lalu-Lintas}

Analisis ini diperlukan untuk mengetahui bagaimana karakteristik lalu lintas pada ruas jalan 4/2D di Sidoarjo. Karakteristik yang dicari adalah Volume kendaraan, hambatan samping, dan kecepatan rata rata. Data yang digunakan dalam menentukan karakteristik lalu lintas terbagi menjadi data primer dan data sekunder. 
Data primer diperoleh dengan cara survei langsung lalu lintas pada lokasi penelitian yang dilakukan dengan menggunakan handy cam yaitu dengan meletakannya pada posisi tertentu sehingga kendaraan yang melewati dapat terekam dengan baik pada setiap ruas jalan yang ditinjau. Setelah perekaman selesai maka jumlah kendaraan dapat dicatat serta dapat mengetahui waktu antara (headway) dari masing-masing komposisi kendaraan yang ditinjau, serta dapat dilakukan pengecekan berulang-ulang sehingga ketelitian data dapat terjaga.

Data sekunder diperoleh dari instansi terkait, dalam penelitian ini BPS Sidoarjo, BAPPEDA Sidoarjo dan DISHUB Sidoarjo, data sekunder juga dapat diperoleh melalui browsing via internet.

Data diolah dengan menggunakan bantuan program komputer yaitu MS-Excel 2003. Data yang diperoleh kemudian diolah hingga diperoleh data yang dibutuhkan untuk melakukan analisis penentuan ekuivalen mobil penumpang pada Jalan perkotaan daerah Sidoarjo.

\section{Analisis Headway}

Analisis penentuan Nilai Ekivalen Mobil Penumpang (EMP) pada penelitian ini menggunakan rumus Headway oleh R.J. Salter [5]. Salter menjelaskan bagaimana menentukan nilai EMP dengan mencatat waktu antara (headway) kendaraan yang berurutan saat kendaraan tersebut melewati suatu titik pengamatan yang telah ditentukan. Rasio headway yang diperlukan mencakup 7 macam kombinasi kendaraan, yaitu :

Light Vehicle (LV) diikuti Light Vehicle (LV)

Light Vehicle (LV) diikuti Heavy Vehicle (HV)

Heavy Vehicle (HV) diikuti Light Vehicle (LV)

Heavy Vehicle (HV) diikuti Heavy Vehicle (HV)

Motor Cycle (MC) diikuti Motor Cycle (MC)

Light Vehicle (LV) diikuti Motor Cycle (MC)

Motor Cycle (MC) diikuti Light Vehicle (LV)

Nilai EMP dihitung dengan persamaan 1:

$t a+t d=t b+t c$

dengan

ta : nilai rata-rata headway LV diikuti LV

tb : nilai rata-rata headway $\mathrm{LV}$ diikuti $\mathrm{MC}$

tc : nilai rata-rata headway $\mathrm{MC}$ diikuti LV

td : nilai rata-rata headway $\mathrm{MC}$ diikuti MC

Keadaan yang dapat memenuhi persamaan di atas sulit diperoleh karena tiap kendaraan mempunyai karakteristik yang berbeda. Demikian juga pengemudi memiliki kemampuan yang berbeda dalam mengemudi. Oleh karena itu, diperlukan koreksi terhadap nilai rata-rata headway dengan persamaan 2 dan 3.

$\left[t a-\frac{k}{n a}\right]+\left[t d-\frac{k}{n d}\right]=\left[t b-\frac{k}{n b}\right]+\left[t c-\frac{k}{n c}\right]$ $k=\left(\frac{n a \times n b \times n c \times n d \times(t a+t d-t c-t b)}{(n d \times n b \times n c)+(n a \times n b \times n c)+(n a \times n d \times n c)+(n a \times n d \times n b)}\right)$

dengan:

na : jumlah data headway LV diikuti LV

$\mathrm{nb}$ : jumlah data headway LV diikuti MC

nc : jumlah data headway MC diikuti LV

nd : jumlah data headway MC diikuti MC

Selanjutnya, nilai rata-rata headway pasangan kendaraan tersebut dikoreksi dengan persamaan 4.

$t a_{k}=t a-\frac{k}{n a}$

$t b_{k}=t b-\frac{k}{n b}$

$t c_{k}=t c-\frac{k}{n c}$

$t d_{k}=t d-\frac{k}{n d}$

Dengan menggunakan nilai rata-rata headway yang sudah dikoreksi tersebut menggunakan persamaan 5 .

$t a_{k}+t b_{k}=t c_{k}+t d_{k}$

dengan

$\mathrm{ta}_{\mathrm{k}}$ : nilai rata-rata headway LV diikuti LV terkoreksi $\mathrm{tb}_{\mathrm{k}}$ : nilai rata-rata headway $\mathrm{LV}$ diikuti MC terkoreksi $\mathrm{tc}_{\mathrm{k}}$ : nilai rata-rata headway $\mathrm{MC}$ diikuti LV terkoreksi $\mathrm{td}_{\mathrm{k}}$ : nilai rata-rata headway $\mathrm{MC}$ diikuti MC terkoreksi

Apabila persyaratan tersebut memenuhi syarat, maka nilai ekivalensi mobil penumpang Motor Cycle dapat dihitung dengan persamaan 6 .

EMP Motor Cycle $(M C)=\frac{t b_{k}}{t a_{k}}$

Karena sampel dipilih acak maka dimungkinkan adanya suatu kesalahan standar deviasi dari distribusi yang dinyatakan sebagai standard error (E) seperti persamaan 7 .

$E=\frac{s}{n^{0,5}}$

dengan:

E : standard error

$\mathrm{s}:$ standar deviasi

$\mathrm{n}$ : Jumlah Sampel

dan standar deviasi :

$S=\sqrt{\frac{1}{(n-1)}} \sum_{i=1}^{n}\left(x_{i}-\overline{\bar{x}}\right)^{2}$

dengan:

$\mathrm{n}$ : jumlah sampel

xi : nilai headway ke-i

$\bar{x}$ : nilai rata-rata sampel headway

Untuk perkiraan nilai rata-rata headway seluruh pasangan kendaraan $(\mu)$ dapat disesuaikan dengan tingkat konfidensi atau keyakinan yang diinginkan (desired level of confidence). Perkiraan ini terletak dalam suatu interval yang disebut interval keyakinan (confidence interval) yang mempunyai batas toleransi kesalahan sebesar e pada persamaan 9 .

$e=K . E$ 
dengan:

$\mathrm{K}$ : tingkat konfidensi distribusi normal

Nilai rata-rata headway untuk distribusi normal $(\mathrm{n} \geq 30)$ dihitung dengan persamaan 10 .

$\mu_{1,2}=\bar{x} \pm e$

dengan:

$\mu_{1,2}:$ Batas keyakinan atas dan bawah nilai rata-rata

$\overline{\mathrm{x}}$ : nilai rata - rata headway

e : batas toleransi kesalahan

Dari analisis ini maka akan didapatkan nilai ekivalen mobil penumpang (EMP) sesuai dengan metode headway yang kemudian akan di analisis kesesuaiannya menggunakan analisis perhitungan kinerja.

\subsubsection{Analisis Kinerja Lalu-Lintas}

Setelah mendapatkan EMP dari kendaraan, analisis yang dilakukan selanjutnya adalah menghitung kinerja ruas jalan untuk tipe 4/2D dengan menggunakan metode MKJI 1997. Analisis kinerja dilakukan untuk mengetahui perbandingan kinerja ruas jalan dengan menggunakan EMP perhitungan serta kinerja ruas jalan dengan menggunakan EMP MKJI 1997.

\section{Hasil dan Pembahasan}

\subsection{Analisis Karakteristik Ruas Jalan}

Data volume lalu lintas didapatkan melalui survey volume lalu lintas yang dilakukan mulai tanggal 21-23 januari 2020. Survey ini dilakukan di 3 ruas jalan yang akan ditinjau, yaitu Jl. Jenggolo, Jl. Majapahit dan Jl. Pahlawan.

Tabel 1 Volume Lalu Lintas per Jam

\begin{tabular}{|c|c|c|c|c|c|c|}
\hline \multirow{2}{*}{ Ruas Jalan } & \multirow{2}{*}{ Jam } & \multirow{2}{*}{ Arah } & \multicolumn{4}{|c|}{ Volume (1 Jam) } \\
\hline & & & LV & $\mathrm{HV}$ & $\mathrm{MC}$ & UM \\
\hline \multirow{6}{*}{ 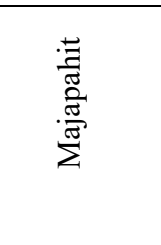 } & \multirow{2}{*}{ Puncak Pagi } & Sidoarjo - Porong & 926 & 33 & 7119 & 48 \\
\hline & & Porong - Sidoarjo & 286 & 5 & 5039 & 41 \\
\hline & \multirow{2}{*}{ Puncak Sore } & Sidoarjo - Porong & 1083 & 52 & 7529 & 27 \\
\hline & & Porong - Sidoarjo & 359 & 8 & 2081 & 6 \\
\hline & \multirow{2}{*}{ Tidak Puncak } & Sidoarjo - Porong & 786 & 79 & 3234 & 19 \\
\hline & & Porong - Sidoarjo & 299 & 4 & 2408 & 14 \\
\hline \multirow{6}{*}{$\begin{array}{l}\circ \\
\stackrel{0}{0} \\
00 \\
000 \\
\stackrel{0}{0}\end{array}$} & \multirow{2}{*}{ Puncak Pagi } & Sidoarjo - Surabaya & 784 & 47 & 8370 & 27 \\
\hline & & Surabaya - Sidoarjo & 995 & 77 & 5953 & 21 \\
\hline & \multirow{2}{*}{ Puncak Sore } & Sidoarjo - Surabaya & 1073 & 70 & 5140 & 35 \\
\hline & & Surabaya - Sidoarjo & 966 & 61 & 8084 & 39 \\
\hline & \multirow{2}{*}{ Tidak Puncak } & Sidoarjo - Surabaya & 916 & 109 & 3028 & 7 \\
\hline & & Surabaya - Sidoarjo & 1003 & 128 & 3177 & 21 \\
\hline \multirow{6}{*}{ 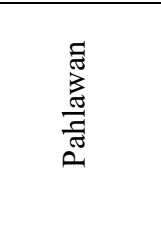 } & \multirow{2}{*}{ Puncak Pagi } & Krian - Sidoarjo & 1500 & 11 & 3899 & 35 \\
\hline & & Sidoarjo - Krian & 1395 & 9 & 2729 & 29 \\
\hline & \multirow{2}{*}{ Puncak Sore } & Krian - Sidoarjo & 1303 & 22 & 2548 & 21 \\
\hline & & Sidoarjo - Krian & 1479 & 14 & 3544 & 29 \\
\hline & \multirow{2}{*}{ Tidak Puncak } & Krian - Sidoarjo & 1140 & 14 & 1968 & 12 \\
\hline & & Sidoarjo - Krian & 1016 & 16 & 1925 & 22 \\
\hline
\end{tabular}

Pengambilan data volume lalu lintas dilakukan dengan cara perekaman menggunakan kamera, maka dari itu pengambilan data di lapangan tidak bisa dilakukan seharian penuh dikarenakan keterbatasan alat perekaman yang didapat. Untuk itu peneliti mengambil beberapa jam yang mewakili waktu yang perlu ditinjau dalam penelitian.

Dari hasil rekapitulasi volume kendaaraan pada masing masing ruas jalan yang akan dianalisis headway dan kinerja ruas jalannya di atas, maka ditentukan 2 jam padat dan 1 jam tidak padat dari ruas jalan mojopahit tersebut, dan didapat untuk jam padat yaitu pukul 06.30-07.30 dan 16.00-17.00 serta untuk jam tidak padat yaitu pukul 08.00-09.00.

\subsection{Analisis Headway}

Data headway pada tiap kendaraan diperoleh dengan cara mensurvey waktu antara kendaraan yang ditinjau, yaitu waktu antara kendaraan ringan - kendaraan ringan (LV-LV), sepeda motor - sepeda motor (MC-MC), kendaraan ringan - sepeda motor (LV-MC), dan sepeda motor-kendaraan ringan (MC-LV). Data tersebut kemudian dianalisis untuk menentukan Ekivalen Mobil Penumpang (EMP) untuk sepeda motor.

Survey headway yang dilakukan yaitu dengan cara mengamati kendaraan yang lewat suatu titik beriringan seperti contoh sepeda motor diikuti sepeda motor berikutnya, perhitungan dilakukan tiap lajur. Pada contoh ruas Jl. Majapahit, 
data headway yang didapat pada 15 menit pertama, yaitu pukul 06.30-06.45. Hasil analisis headway didapatkan nilai EMP sebesar 0.32 .

Untuk rekapitulasi nilai EMP pada Jalan Mojopahit dapat dilihat pada Tabel 2.

Tabel 2 Rekapitulasi EMP Sepeda Motor pada Jl. Mojopahit arah Sidoarjo-Porong

\begin{tabular}{|c|c|c|c|}
\hline \multicolumn{2}{|c|}{ Waktu Survey } & EMP & $\begin{array}{c}\text { Rata-rata } \\
\text { EMP }\end{array}$ \\
\hline \multirow{4}{*}{ 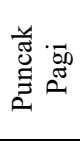 } & $06.30-06.45$ & 0.32 & \multirow{4}{*}{0.34} \\
\hline & $06.45-07.00$ & 0.25 & \\
\hline & $07.00-07.15$ & 0.38 & \\
\hline & $07.15-07.30$ & 0.38 & \\
\hline \multirow{4}{*}{ 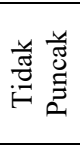 } & $08.00-08.15$ & 0.14 & \multirow{4}{*}{0.23} \\
\hline & $08.15-08.30$ & 0.48 & \\
\hline & $08.30-08.45$ & 0.26 & \\
\hline & $08.45-09.00$ & 0.06 & \\
\hline \multirow{4}{*}{ 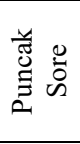 } & $16.00-16.15$ & 0.88 & \multirow{4}{*}{0.85} \\
\hline & $16.15-06.30$ & 0.86 & \\
\hline & $16.30-16.45$ & 0.88 & \\
\hline & $16.45-17.00$ & 0.76 & \\
\hline
\end{tabular}

Hasil rekapitulasi nilai EMP sepeda motor pada Jl. Majapahit, Jl. Pahlawan dan J1. Jenggolo dapat dilihat pada Tabel 3. Dari Tabel 3 dapat dilihat bahwa nilai EMP tertinggi pada Ruas Jalan Majapahit yaitu sebesar 0,558 pada jam puncak sore arah Sidoarjo-Porong. Untuk Ruas jalan Pahlawan yaitu sebesar 0,38 pada jam tidak puncak arah Sidoarjo-Krian. Serta untuk Jalan Jenggolo yaitu sebesar 0,81 pada jam puncak sore arah Sidoarjo-Surabaya.

Tabel 3 Rekapitulasi EMP Sepeda Motor

\begin{tabular}{|c|c|c|c|}
\hline & Nama Jalan & Waktu Survey & EMP \\
\hline \multirow{6}{*}{ 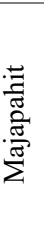 } & Sidoarjo - Porong & Puncak Pagi & 0.34 \\
\hline & \multirow{5}{*}{ Porong - Sidoarjo } & Tidak Puncak & 0.23 \\
\hline & & Puncak Sore & 0.558 \\
\hline & & Puncak Pagi & 0.25 \\
\hline & & Tidak Puncak & 0.32 \\
\hline & & Puncak Sore & 0.23 \\
\hline \multirow{6}{*}{ 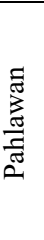 } & Krian - Sidoarjo & Puncak Pagi & 0.17 \\
\hline & \multirow{5}{*}{ Sidoarjo - Krian } & Tidak Puncak & 0.24 \\
\hline & & Puncak Sore & 0.30 \\
\hline & & Puncak Pagi & 0.22 \\
\hline & & Tidak Puncak & 0.38 \\
\hline & & Puncak Sore & 0.13 \\
\hline \multirow{6}{*}{ 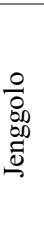 } & Sidoarjo - Surabaya & Puncak Pagi & 0.42 \\
\hline & \multirow{5}{*}{ Surabaya - Sidoarjo } & Tidak Puncak & 0.51 \\
\hline & & Puncak Sore & 0.81 \\
\hline & & Puncak Pagi & 0.23 \\
\hline & & Tidak Puncak & 0.39 \\
\hline & & Puncak Sore & 0.26 \\
\hline
\end{tabular}

\subsection{Analisis Kinerja Lalu-lintas}

Analisis ini dilakukan untuk membandingkan kinerja ruas jalan yang ditinjau menggunakan EMP hasil perhitungan dengan EMP metode MKJI 1997.

Berdasarkan data volume lalu lintas perjam pada masing masing ruas jalan yang ditinjau, kemudian dilakukan analisis kinerja lalu lintas menggunakan EMP metode MKJI 1997 dan EMP hitungan. Hasil dari Analisis kinerja lalu lintas menggunakan EMP metode MKJI 1997 dapat dilihat pada Tabel 4. Pada Tabel 4 didapatkan hasil kinerja untuk Ruas Jalan Majapahit tertinggi yaitu pada jam puncak sore dengan nilai derajat kejenuhan sebesar 0,867. Untuk Ruas Jalan Jenggolo tertinggi yaitu pada jam puncak sore dengan nilai derajat kejenuhan sebesar 0,976. Untuk Ruas Jalan Pahlawan tertinggi yaitu pada jam puncak sore dengan nilai derajat kejenuhan sebesar 0,805 .

Kemudian hasil analisis kinerja menggunakan EMP perhitungan headway dapat dilihat pada Tabel 5. Dari Tabel 5 didapatkan hasil kinerja untuk Ruas Jalan Majapahit tertinggi yaitu pada jam puncak sore dengan nilai derajat kejenuhan sebesar 1,513. Untuk Ruas Jalan Jenggolo tertinggi yaitu pada jam puncak sore dengan nilai derajat kejenuhan sebesar. Untuk Ruas Jalan Pahlawan tertinggi yaitu pada jam puncak pagi dengan nilai derajat kejenuhan sebesar 0,694 .

Tabel 4 Analisis Kinerja Lalu Lintas Menggunakan EMP MKJI 1997

\begin{tabular}{|c|c|c|c|c|}
\hline Ruas Jalan & Jam & Q & $\mathrm{C}$ & DS \\
\hline \multirow{6}{*}{ 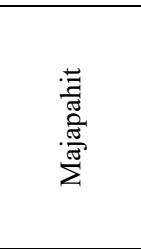 } & \multirow{2}{*}{ Puncak Pagi } & 2746 & 3493 & 0.786 \\
\hline & & 1552 & 3493 & 0.444 \\
\hline & \multirow{2}{*}{ Puncak Sore } & 3027 & 3493 & 0.867 \\
\hline & & 889 & 3493 & 0.255 \\
\hline & \multirow{2}{*}{ Tidak Puncak } & 1690 & 3493 & 0.484 \\
\hline & & 906 & 3493 & 0.259 \\
\hline \multirow{6}{*}{$\begin{array}{l}\circ \\
\stackrel{0}{0} \\
00 \\
00 \\
\stackrel{0}{\varrho}\end{array}$} & \multirow{2}{*}{ Puncak Pagi } & 2933 & 3066 & 0.957 \\
\hline & & 2575 & 3135 & 0.821 \\
\hline & \multirow{2}{*}{ Puncak Sore } & 2442 & 3066 & 0.796 \\
\hline & & 3060 & 3135 & 0.976 \\
\hline & \multirow{2}{*}{ Tidak Puncak } & 1804 & 3066 & 0.588 \\
\hline & & 1951 & 3135 & 0.622 \\
\hline \multirow{6}{*}{ 胥 } & \multirow{2}{*}{ Puncak Pagi } & 2488 & 3135 & 0.794 \\
\hline & & 2088 & 2959 & 0.706 \\
\hline & \multirow{2}{*}{ Puncak Sore } & 1966 & 3135 & 0.627 \\
\hline & & 2382 & 2959 & 0.805 \\
\hline & \multirow{2}{*}{ Tidak Puncak } & 1649 & 3135 & 0.526 \\
\hline & & 1516 & 2959 & 0.512 \\
\hline
\end{tabular}


Tabel 5 Analisis Kinerja Lalu Lintas Menggunakan EMP Headway

\begin{tabular}{|c|c|c|c|c|}
\hline Ruas Jalan & Jam & $\mathrm{Q}$ & $\mathrm{C}$ & DS \\
\hline \multirow{6}{*}{ 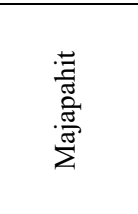 } & Puncak Pagi & 3386 & 3493 & 0.969 \\
\hline & & 1552 & 3493 & 0.444 \\
\hline & Puncak Sore & 5286 & 3493 & 1.513 \\
\hline & & 847 & 3493 & 0.242 \\
\hline & Tidak Puncak & 1625 & 3493 & 0.465 \\
\hline & & 1074 & 3493 & 0.307 \\
\hline \multirow{6}{*}{$\begin{array}{l}0 \\
0 \\
00 \\
00 \\
0 \\
0\end{array}$} & Puncak Pagi & 4356 & 3066 & 1.421 \\
\hline & & 2457 & 3135 & 0.784 \\
\hline & Puncak Sore & 5320 & 3066 & 1.735 \\
\hline & & 3141 & 3135 & 1.002 \\
\hline & Tidak Puncak & 2591 & 3066 & 0.845 \\
\hline & & 2396 & 3135 & 0.764 \\
\hline \multirow{6}{*}{ 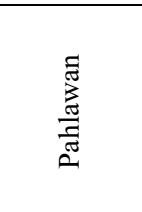 } & Puncak Pagi & 2176 & 3135 & 0.694 \\
\hline & & 2006 & 2959 & 0.678 \\
\hline & Puncak Sore & 2094 & 3135 & 0.668 \\
\hline & & 1957 & 2959 & 0.661 \\
\hline & Tidak Puncak & 1629 & 3135 & 0.520 \\
\hline & & 1767 & 2959 & 0.597 \\
\hline
\end{tabular}

Tabel 6 Perbandingan Analisis Kinerja Menggunakan EMP MKJI 1997 dan EMP Headway

\begin{tabular}{|c|c|c|c|}
\hline $\begin{array}{l}\text { Ruas } \\
\text { Jalan }\end{array}$ & Jam & $\begin{array}{c}\text { DS EMP } \\
\text { MKJI }\end{array}$ & $\begin{array}{l}\text { DS EMP } \\
\text { Headway }\end{array}$ \\
\hline \multirow{6}{*}{ 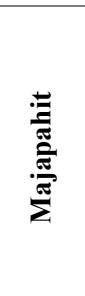 } & \multirow[b]{2}{*}{ Puncak Pagi } & 0.786 & 0.969 \\
\hline & & 0.444 & 0.444 \\
\hline & \multirow{2}{*}{ Puncak Sore } & 0.867 & 1.513 \\
\hline & & 0.255 & 0.242 \\
\hline & \multirow[b]{2}{*}{ Tidak Puncak } & 0.484 & 0.465 \\
\hline & & 0.259 & 0.307 \\
\hline \multirow{6}{*}{ 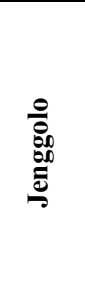 } & \multirow[b]{2}{*}{ Puncak Pagi } & 0.957 & 1.421 \\
\hline & & 0.821 & 0.784 \\
\hline & \multirow[b]{2}{*}{ Puncak Sore } & 0.796 & 1.735 \\
\hline & & 0.976 & 1.002 \\
\hline & \multirow[b]{2}{*}{ Tidak Puncak } & 0.588 & 0.845 \\
\hline & & 0.622 & 0.764 \\
\hline \multirow{6}{*}{ 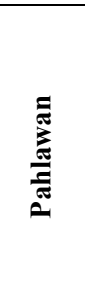 } & \multirow[b]{2}{*}{ Puncak Pagi } & 0.794 & 0.694 \\
\hline & & 0.706 & 0.678 \\
\hline & \multirow[b]{2}{*}{ Puncak Sore } & 0.627 & 0.668 \\
\hline & & 0.805 & 0.661 \\
\hline & \multirow{2}{*}{ Tidak Puncak } & 0.526 & 0.520 \\
\hline & & 0.512 & 0.597 \\
\hline
\end{tabular}

Dari hasil tabel 5 dapat disimpulkan bahwa volume kendaraan yang besar, dan nilai EMP yang besar pula sangat mempengaruhi jumlah volume arus lalu lintas, sehingga derajat kejenuhannya semakin besar.
Perbandingan kinerja ruas jalan menggunakan metode MKJI 1997 dengan Headway dapat dilihat pada Tabel 6.

Tabel 6 merupakan perbandingan hasil analisis kinerja jalan menggunakan EMP MKJI 1997 dan EMP Headway. Perbandingan tersebut beberapa terlihat sangat signifikan, dan EMP Headway terlihat cenderung lebih besar derajat kejenuhannya. Perbedaan ini dapat disebabkan oleh perbedaan kondisi arus lalu lintas pada tahun 1997 dengan arus lalu lintas saat ini, perubahan tersebut contohnya adalah, jumlah kendaraan, karakteristik kendaraan, kondisi geometri jalan, serta perbedaan fasilitas kendaraan yang diperoleh.

Besarnya nilai EMP dipengaruhi oleh faktor karakteristik operasional kendaraan, jalan, lingkungan, dan kondisi pengendalian lalu lintas [11][12][13]. Nilai EMP pada analisis Headway berbeda tiap jalurnya dikarenakan variabel utama dari analisis ini adalah waktu, sehingga nilai ini tergantung pada pengendara dan kondisi lalu lintas tiap jalurnya. Dari hasil perhitungan diketahui perbandingan antara Ekivalen Mobil Penumpang dengan Volume lalu lintas rata-rata menunjukkan hasil bahwa semakin tinggi nilai EMP maka semakin besar pula Volume lalu lintasnya, namun hal ini tergantung pada jumlah kendaraan sepeda motor yang melewati jalan tersebut.

\section{Simpulan}

Berdasarkan hasil analisis dapat disimpulkan beberapa hal sebagai berikut:

1. Dari hasil perhitungan volume per jam, maka dapat ditentukan 2 jam puncak dan 1 jam tidak puncak,. Pada Jl. Mojopahit untuk jam puncak yaitu pukul 06.30-07.30 dan 16.00-17.00 serta untuk jam tidak puncak yaitu pukul 08.00-09.00. Pada J1. Pahlawan untuk jam puncak yaitu pukul 06.15 - 07.15 dan 16.00 - 17.00 serta untuk jam tidak puncak yaitu pukul 10.00 - 11.00. Pada Jl. Jenggolo untuk jam puncak yaitu pukul 06.15 - 07.15 dan $16.00-$ 17.00 serta untuk jam tidak puncak yaitu pukul 11.30 12.30 .

2. Hasil EMP sepeda motor untuk ruas Jl. Mojopahit arah Sidoarjo-Porong yaitu 0,34 pada jam puncak pagi, 0,23 pada jam tidak puncak,dan 0,55 pada jam puncak sore, serta untuk arah Porong-Sidoarjo yaitu 0,25 pada jam puncak pagi, 0,32 pada jam tidak puncak, dan 0,23 pada jam puncak sore. Selanjutnya untuk ruas Jl. Pahlawan arah Krian-Sidoarjo yaitu 0,17 pada jam puncak pagi, 0,24 pada jam tidak puncak,dan 0,30 pada jam puncak sore, serta untuk arah Sidoarjo-Krian yaitu 0,22 pada jam puncak pagi, 0,38 pada jam tidak puncak, dan 0,13 pada jam puncak sore. Dan untuk ruas J1. Jenggolo arah Sidoarjo-Surabaya yaitu 0,42 pada jam puncak pagi, 0,51 pada jam tidak puncak,dan 0,81 pada jam puncak sore, 
serta untuk arah Sidoarjo-Krian yaitu 0,23 pada jam puncak pagi, 0,39 pada jam tidak puncak, dan 0,26 pada jam puncak sore.

3. Hasil perhitungan menunjukkan bahwa nilai emp cenderung berubah menjadi lebih besar jika dibandingkan dengan nilai emp MKJI 1997. Perbandingan kinerja ruas jalan pada saat menggunakan EMP MKJI dan EMP headway memiliki hasil yang signifikan. Perbandingan Derajat Kejenuhan terbesar berada pada jam puncak sore pada ruas J1. Majapahit arah Sidoarjo-Porong yaitu mencapai selisih 0,646. Pada J1. Jenggolo perbandingan terbesar berada pada jam puncak sore arah Sidoarjo Surabaya yaitu mencapai selisih 0,939. Pada Jl. Pahlawan perbandingan terbesar berada pada jam puncak sore arah Sidoarjo - Krian yaitu mencapai selisih 0,144. Perbedaan ini disebabkan karena adanya perbedaan volume kendaraan, karakteristik lalu lintas, geometrik jalan pada ruas jalan saat ini

\section{Daftar Pustaka}

[1] Departemen Pekerjaan Umum, "Highway Capacity Manual Project (HCM)," Man. Kapasitas Jalan Indones., vol. 1, no. I, p. 564, 1997.

[2] Badan Pusat Statistik Kabupaten Sidoarjo, Sidoarjo Dalam Angka. Sidoarjo, 2016.

[3] N. R. Council and TRB, Highway capacity manual. 2000 .

[4] A. Setiawan, "Studi penentuan nilai ekivalensi mobil penumpang (emp) berbagai jenis kendaraan pada ruas jalan utama di kota palu," J. Rekayasa dan Manaj. Transp., vol. I No. 1, pp. 16-26, 2011.

[5] R. J. Salter, Highway Traffic Analysis and Design, 3rd ed., vol. 53, no. 9. London: Macmillan Education UK, 1996.
[6] J. Ambros and M. Kyselý, "Free-flow vs carfollowing speeds: Does the difference matter?," $A d v$. Transp. Stud., no. 40, pp. 17-26, 2016, doi: 10.4399/97888548970072.

[7] H. Iskandar, "Cara Pemutakhiran Nilai Ekivalen Mobil Penumpang dan Kapasitas Dasar Ruas Jalan Luar Kota." .

[8] E. L. Seguin, Passenger Car Equivalents on Urban Freeways. U.S. Federal Highway Administration, Offices of Reesearche and Development, 1982.

[9] R. A. Krammes and K. W. Crowley, "Passenger Car Equivalents for Trucks on Level Freeway Segments.," Transp. Res. Rec., pp. 10-17, 1986.

[10] G. R. Prima, H. Iskandar, and T. B. Joewono, "Kajian Nilai Ekivalensi Mobil Penumpang Berdasarkan Data Waktu Antara Pada Ruas Jalan TOL," African Asian Stud., vol. 35, no. 4, pp. 430-434, 2002, doi: $10.1163 / 156852100512347$

[11] J. S. Yeung, Y. D. Wong, and J. R. Secadiningrat, "Lane-harmonised passenger car equivalents for heterogeneous expressway traffic," Transp. Res. Part A Policy Pract., vol. 78, pp. 361-370, 2015, doi: 10.1016/j.tra.2015.06.001

[12] S. Putra, "The correction value of passenger-car equivalents for motorcycle and its impact to road performance in developing countries," Procedia -Soc. Behav. Sci., vol. 16, no. December, pp. 400-408, 2011, doi: 10.1016/j.sbspro.2011.04.461.

[13] P. Saha, Q. S. Hossain, H. M. I. Mahmud, and Z. Islam, "Passenger car equivalent (PCE) of through vehicles at signalized intersections in Dhaka metropolitan city, Bangladesh," IATSS Res., vol. 33, no. 2, pp. 99-104, 2009, doi: 10.1016/S03861112(14)60248-X. 
Halaman ini sengaja dikosongkan 